\title{
Kırsal Kesime Atanan Türkçe ve Sınıf Öğretmenlerinin Mesleğe Uyum Süreci
}

\author{
Dr. Öğr. Üyesi Kenan BULUT** \\ Yüzüncü Y1l Üniversitesi, Eğitim Fakültesi, Zeve Kampüsü, Van / Türkiye, \\ kenanbulut80@yyu.edu.tr, ORCID: 0000-0003-4771-0459 \\ Dr. Öğr. Üyesi Hatice COŞKUN \\ Yüzüncü Yıl Üniversitesi, Eğitim Fakültesi, Zeve Kampüsü, Van / Türkiye, \\ haticecoskun2008@hotmail.com, ORCID: 0000-0002-0453-8700
}

\section{$\ddot{\mathbf{O z}}$}

Bu çalışmanın amacı, kırsal kesimde çalışan Türkçe ve sınıf öğretmenlerinin mesleğe başladıkları ilk yıllarda karşılaştıkları sorunları tespit etmek ve bunların giderilmesine yönelik çözüm önerilerini ortaya koymaktır. Çalışma Van ilinin kırsal kesiminde çalışan Türkçe ve sınıf öğretmenleriyle yürütülmüştür. Çalışma için özellikle Türkçe ve sınıf öğretmenlerinin seçilmesinin sebebi, kırsal kesimdeki öğretmenlerin mesleklerini icra ederken karşılaştıkları ilk ve belki de en önemli problemin dil ve iletişim ile ilgili olmasıdır. Bu durum, Türkçe ve sınıf öğretmenlerinin kırsal kesimde görev yapan öğretmenler arasında söz konusu problemlerle karşılaşan ilk kesim öğretmenler oldukları anlamına gelmektedir. Çalışmada öğretmenlerin ne tür sorunlarla karşılaştıkları, sorunları nasıl çözdükleri ve daha farklı ne tür çözüm önerileri sundukları tespit edilmeye çalışılmıştır. Verilerin toplanmasında araştırmacılar tarafından geliştirilen "Kırsal Kesime Atanan Türkçe ve SınıfÖ Ŏretmenlerinin Mesleğe Uyum Süreci

* Sorumlu Yazar. Tel: +90 5055735844

(C) 2018 Kalem Eğitim ve Sağlık Hizmetleri Vakfı. Bütün Hakları Saklıdır. 
ile İlgili Görüş Alma Formu” kullanılmıştır. Veriler içerik analizi ile çözümlenmiştir. Çalışmanın bulguları alanyazında yer alan benzer çalışmalarla karşılaştırılarak tartışılmıştır. Bütün bu merhalelerden sonra ilgili kurum ve kuruluşlara, kişilere, idarecilere ve en önemlisi mesleğe yeni başlayan kırsal kesim öğretmenlerine yönelik önerilere yer verilmiştir.

Anahtar Kelimeler: Türkçe ve sınıf öğretmenleri; Kırsal kesim; Mesleğe uyum süreci.

\title{
Turkish Language Teachers' and Primary School Teachers' Working at Rural Areas Orientation Process to the Teaching Profession
}

\begin{abstract}
The aim of this study is to determine the problems of Turkish and primary school teachers encounter in the first years of teaching profession and reveal solution offers to eliminate these problems. The study was included Turkish and primary school teachers working rural areas in Van. The reason for especially selecting Turkish Language teachers and primary school teachers for this study is that primary and maybe the foremost problem is about language and communication that teachers at rural areas confront while practicing their profession. So, it means that Turkish and primary school teachers are first teachers faced with these language and communication problems. It is tried to find out what kind of problems teachers have, how they deal with these problems and what kinds of solution offer they suggest. "Receiving Opinions of Turkish Language Teachers and Primary School Teachers Who Were Appointed to the Rural Areas About Professional Orientation Process Form" which was developed by researchers was used to obtain data. Data were analyzed with content analysis. Findings of this research were discussed comparing similar researches. After all stages, some suggestions were included towards relevant institutions and organizations, people, managers most of all beginner teachers working in rural areas.
\end{abstract}

Keywords: Turkish Language teachers and primary school teachers; Rural areas; Orientation process. 


\section{Extended Summary}

\section{Purpose}

For a qualified education, primarily, it is mandatory to remove the negative situations that obstruct the productivity of education. Thus, it has great importance to determine problems of teachers in general and in particular teachers who work at rural areas and to think about what to do to resolve these problems.

The aim of this study is to determine the problems of beginner Turkish Language teachers and primary school teachers who work at rural areas and to propose solutions intended to resolve these problems. It is a well-known fact that newly graduate young teachers who are appointed to areas that they might have never known before are in need of orientation because of both settling to a new place and entering upon a new career (Toker-Gökçe, 2013, p.143). Hence, the aforementioned problems of teachers and addressing to their orientation process with reference to these problems' solutions are within the scope of this study. The study was conducted with Turkish Language teachers and primary school teachers who work at rural areas of Van province. The reason for especially selecting Turkish Language teachers and primary school teachers for the study is that first and maybe the foremost problem are about language and communication that teachers at rural areas confront while practicing their profession. This situation means that Turkish Language teachers and primary school teachers are the first ones to confront the mentioned problems among teachers who work at rural areas.

"Scientific research should be taken as a basis in solutions of existing problems in education, preparation and implementation of planning appropriate to country realities" (Dikenoğlu, 1992, p.448). Based on this, with this study, it is aimed to scientifically determine problems greatly mentioned about rural. In this study, it is attempted to determine what kind of problems teachers encounter, how they resolve these problems and what kind of different solutions they propose and thus knowledge and experiences that are important for professional solidarity and collaboration are shared.

\section{Method}

In this research which was designed as case study, data were collected with qualitative research method. One of data collection techniques in qualitative researches is to get individuals' opinions. 
20 teachers 11 of whom being primary school teachers and 9 of whom being Turkish Language teachers working in rural areas of Van, one of the provinces located in the eastern part of Turkey, composed the study group of the research. Especially teachers who were working at distal villages and districts were aimed to reach in determining the study group. Teachers who had professional experience between 1-3 years attended to the study.

"Receiving Opinions of Primary School Teachers and Turkish Language Teachers Who were Appointed to the Rural Areas About Professional Orientation Process Form" which developed by researchers was used in data collection. Related literature was benefited from and experts' opinions were consulted for validity in preparing the form. Inter-rater reliability was applied for reliability. Content analysis, being one of the qualitative data analyze techniques, was used for data analysis.

\section{Result}

Problems of primary school teachers and Turkish Language teachers and their solutions for these problems and thus the aforementioned teachers' professional orientation process were addressed in this study.

Educational institutions and teachers working in these institutions have an important role in the orientation of individuals who form the society to emerging changes and contribution to the society (İzci, Duran and Taşar, 2010). Various problems that teachers in general and in particular teachers who work at rural areas encounter come into question. While most of these problems are related to the conditions in rural areas, some of them occur because of the fact that Ministry of National Education, education faculties and other stakeholders do not fulfill their responsibilities as required.

It is seen that academic achievement in Turkish education system is the foreground (Y1ldirım, 2010). This means that teacher candidates do not practice enough in the undergraduate program. However, professional teaching ability is a skill that can be acquired with more practice. Teachers who attended this study emphasized that it is necessary to attach more importance to practice than theory, too.

1. Some of the problems revealed in this study are about technological incompetency, material deficiency, adverse economic conditions, communication, transportation, sheltering, heating, limited school facilities, environmental conditions, and traditional thought. 
2. Teachers have mentioned about various socio-cultural problems. In this study teachers have generally complained about indifference to social activities. It is believed that this indifference is especially derived from the fact that there are not enough opportunities for social activities in villages.

3. In this study, teachers have pointed out that they try to resolve the problems that they mentioned above by displaying exemplary behaviors, dealing with students individually, having a solution oriented and fond approach to the problems, being in collaboration with colleagues, being in collaboration with administration, learning with students mutually (language-culture), trying to be in contact with parents, doing additional practices for educational problems.

4. In this study, teachers have frequently mentioned about students' and families' unconsciousness, and parents' indifference.

5. Solutions that teachers propose to educational stakeholders are to equalize the schools' physical conditions and educational materials with central schools, to support teachers (moral-material), to prepare teachers to difficult conditions (village schools, multi-grade class), to enable teachers to do internship at rural areas, colleges of education' being in close contact and collaboration with Ministry of National Education, to give importance to collaboration between school and family, teachers' commitment to their profession by preparing themselves for any circumstances, teachers' being patient, teachers' showing their love to the students and treating them equally, and teachers' not having great expectations.

One of the most important reasons triggering the problems mentioned both in this study and the studies in the "Results and Discussion" part is undoubtedly that teachers working at the rural areas are less experienced. As Gibbs (2000) states, teachers at rural areas are less experienced and younger. Thus, teachers working at these places ask for appointment more frequently because of the mentioned negations.

\section{Suggestions}

1. Ministry of National Education should fulfill all the needs of teachers in villages who work at the rural areas, ministry should 
especially treat more sensitively about improvement of physical conditions.

2. There should be courses at the undergraduate programs intended to prepare teachers to overcome the problems (especially language and communication) that teachers will encounter when they are appointed to rural areas.

3. Practicum should not be given just at the senior year, this course should start at the sophomore year and it should be given within the whole process. Besides, students should be provided with the opportunity to take this course at rural areas.

4. It is under the responsibility of colleges of education to train teacher candidates that they can work anywhere in Turkey and in all circumstances.

Therefore, all teacher candidates, especially primary school teacher candidates and Turkish Language teacher candidates should be trained accordingly so that they can teach at rural areas, especially at the rural areas of the provinces located in the Eastern Anatolia and Southeastern Anatolia Regions. This can be achieved by a 'student exchange program' like Farabi Program.

1. The community should be enlightened on this topic by giving various seminars at villages for the solutions of certain problems arising from traditional life at rural areas.

2. Studies should be carried out to resolve the problems about education by doing researches about social and psychological conditions of the students in rural areas.

3. Faculties of education should carry out studies to enable teacher candidates to gain professional experience by being in collaboration with Ministry of National Education (voluntary teaching).

4. Teaching practicum should be given more importance, the practices should be carried out in a planned and programmed way under the control of faculty members. 
5. Consequently, the implementations that prepare teachers to the profession and the courses preparatory for any circumstances should be focused on more by examining teacher training programs.

\section{Giriş}

Nitelikli eğitim, birçok önemli unsurun bir araya gelmesiyle oluşan bir bileşendir. Öğretim programları, öğretmen yetiştiren kurumlar ve öğretmenler bunlardan bazılarıdır. Öğretmen, toplumların eğitim politikalarının hedefe ulaşmasında kilit rol oynayan yegâne unsurlardan birisidir. Sağ (2007, s.1), gerek toplumsal, siyasal ve ekonomik alanda yaşanan problemlerin çözümünde gerekse sözü edilen eğitim olgusunu bilimsel temelde ve sistematik bir şekilde eyleme dönüştürmede önemli payın şüphesiz öğretmenlere ait olduğunu ifade eder. "Bu gücünden dolayı ögretmenlik kavramı, kimi eğitim anlayışlarında, sözgelimi ilerlemecilik ile bu anlayışın bir türevi olarak değerlendirilen yeniden inşacılık/kurmacılık anlayışlarında bir değişim ajanı olarak tanımlanmaktadır." (Gutek, 2001'den akt; Sağ, 2007, s.1). Realistler öğretmeni hem bilgi sahibi olma konusunda hem de öğretim yeteneği bak1mından profesyonel bir öğretici olarak görmektedirler (Gutek, 1988).

Öğretmenlerin hedef kitlesi ilk ve ortaöğretim çağındaki öğrencilerdir. Dolayısıyla köy, kasaba, ilçe merkezleri, il merkezleri, metropoller kısaca hedef kitlenin bulunduğu bütün yerleşim birimleri öğretmenler için görev yeridir. Söz konusu yerleşim birimleri iki grupta ele alınabilir: Kırsal kesim ve kentsel alanlar. Webster ve Fisher (2000) kırsalın tanımının yerin büyüklüğü, nüfus yoğunluğu, coğrafi dağılım ve ekonomik faaliyetleri içerebileceğini; sosyo-kültürel yönden ise hayat tarzı, değerler ve davranış normlarının kırsalı tanımlayabileceğini ifade eder. Parsons (1996)'a göre de kırsal alan ekonomik, coğrafî, fiziksel ve sosyal olarak hayatlarını kısıtlayan dezavantajlardan etkilenen bireylerin yaşadığı yerdir (akt; Anılan, Kılıç ve Demir, 2015). Elbette hizmet ve insanlara erişim de kırsal için önemli belirleyicilerdir (Webster ve Fisher, 2000).

Ülkemiz açısından bir değerlendirme yapıldığında Türkiye İstatistik Kurumu [TÜİK] verilerine göre 2011 y1lında toplam nüfusun \%23.2'si belde ve köylerde yaşarken, bu oran 2014 yılında \%8.2'ye, 2015 y1lında ise \%7.9'a düşmüştür. Dikkat edildiğinde kır nüfusunun toplam nüfus içerisindeki oranı gittikçe azalmaktadır. Bu durum kırsaldaki hayat koşullarında göçü engelleyecek herhangi bir iyileşmenin olmadığını göstermektedir. Bunda özellikle sağlık ve eğitim alanlarında yaşanan sıkıntıların etkisi büyüktür. Gül (2014), 
Doğu ve Güney Doğu'ya gidildikçe okullaşma oranının azaldığına dikkat çekmektedir. Gedikoğlu (2005) ise yüksek nüfus artış hızı ve kırsal kesimden kentlere doğru göçün eğitim sistemimizi ciddi bir biçimde zorladığını ve sistemin altyapısındaki bölgesel farklılıkların eğitimde firsat ve imkân eşitliğini ortadan kaldırdığını vurgulamaktadır. Bu durumun doğurduğu olumsuzluklar ülkenin doğusunda daha fazla hissedilmektedir.

Kırsal kesimdeki hayat şekli ile kentlerdeki hayat şekli birbirinden farklılık gösterdiğinden eğitim faaliyetlerinde birbirinden farklı durumlar ortaya çıkmaktadır. Bu farklılıklar, kırsal alanların birçok yönden eğitim üzerindeki olumsuz etkisi şeklinde kendisini gösterir. Horn (1995)'nun McREL (Mid-continent Regional Educational Laboratory)'in bir yayınından yaptığı alıntıya göre bu olumsuzluklar kırsal kesimde özellikle küçük okullarda sadece temel derslerin sınırlı olarak verilmesi, öğretmenlerin tek uzman olmaları nedeniyle birçok ders için hazırlık yapmak zorunda kalmaları, kendilerine çok az zaman ayırabilmeleri; eğitimi geliştirme, araştırma ve profesyonel değişim için imkânların bütçe ve uzaklıkla sınırlı olması, birçok kırsal alanın çeşitli ekonomik sıkıntılarının olması şeklinde ifade edilmektedir. Burada ifade edilenlerin dışında kırsal alan barınma, dil ve iletişim kurma, kaynak bulma, hedef kitle, okula ve derslere olan ilgi, velilerle olan iletişim, sosyal ortam, çevre koşulları, ulaşım gibi daha birçok alanda sorunların yoğun olarak yaşandığı alandır. Bu sorunların giderilmesinde kırsal kesimdeki eğitimin niteliğinin arttırılmasında öğretmenlere çokça iş düştüğü bir gerçektir.

"Kırsal alanlarda yaşayan bireylerin de tıpk kentlerde yaşayan bireyler gibi temel sosyal ve meslekî yaşam becerileri kazanabilmeleri, kentsel alan ve kirsal alandaki geliş̧menin dengeli bir biçimde olabilmesi için kırsal alanlarda da eğitim sisteminin işlevsel ve başarılı olmasina ve ĕgitim sisteminin parçası olan ögretmenlere bağlıdır." (Anılan, Kılıç ve Demir, 2015, s.154).

Sınıftaki öğrenme ortamının düzenlenmesi, kazanımlara yönelik etkinliklerin hazırlanması, ders araç-gereçlerinin belirlenmesi, kazanımlara uygun öğretim yöntem ve tekniklerin belirlenmesi ve tamamlayıcı değerlendirme araçlarının seçilmesi gibi değişkenler öğretmenlerin sorumlulukları arasında yer almaktadır (Aslan, 2013). Bununla birlikte kırsala has birtakım problemlerin öğretmenlerin çabalarını zayıflattığı ve buralarda başarının sınırlı kaldığı da gözlemlenmektedir. Özpınar'ın da belirttiği gibi köylere götürülen eğitim hizmetleri gerek içerik gerekse kalite bakımından ne kadar üstün olursa olsun, köylü-öğretmen ve köylü-okul ilişkileri, götürülen hiz- 
metin başarısını etkisi altına almaktadır (Özpınar, 2008). Bu nedenle özellikle köy öğretmenlerinin sadece öğrenciyle değil, köylüyle de olan ilişkileri, uyumu, köylülerin okul ve öğretmene bakış açısı, yaklaşımı önem arz etmektedir.

Türkiye'de öğretmenlik mesleği öteden beri sorunlarla anılan bir meslek olmuştur ${ }^{1}$. Bu durumun eğitimde ve öğretmenlik mesleğinde var olagelen sorunların bir türlü çözüme kavuşturulmamasından kaynaklandığ düşünülmektedir. Söz konusu kırsal olunca öğretmenlik mesleğinin icrasındaki sorunlar daha farklı boyutlar kazanmaktadır. Çünkü "Kırsalın kendi yapısı içinde var olan coğrafí, demografik, ekonomik ve sosyo-kültürel dezavantajların kırsal eğitimi olumsuz yönde etkilediği bilinen bir gerçektir." (Turan ve Garan, 2008, s.117). Bu etki en çok da yeni atanan öğretmenlerde görülmektedir. Özellikle atamalarının ilk yıllarında doğuda ve kırsal kesimde görev yapan sınıf öğretmenleri, öğretmen gruplarının içinde sayıca en fazla olan grubu oluşturmaktadır (Taşkaya, Turhan ve Yetkin, 2015). Eğitim ile ilgili yapılan bir çalıştayda katılımcılar, öğretmenlerin mesleğe karşı daha ilk yıllarında olumsuz bir tutum geliştirmelerinin sebeplerinden birisi olarak, aday öğretmenlerin, ilk görevlerine sosyal ve kültürel yönden aşina olmadıkları bölgelerde başlamaları ve Türkçe bilmeyen öğrencilere eğitim verirken zorluk yaşamaları gösterilmiştir (Eğitim Reformu Girişimi-Eğitim İzleme Raporu, 2011).

Elbette söz konusu problemlerin çözümünde veya azaltılmasında, sadece öğretmenlerin vereceği çaba yetmeyecektir. Eğitim programları hazırlanırken bu durumun dikkate alınması da son derece önemlidir. Yapılan çalışmalarda bu durumun göz ardı edildiği ifade edilmektedir. Turan ve Garan (2008) Türkiye'de program geliştirme sürecinde kırsal kesim koşullarının dikkate alınmadığını belirterek kırsal kesimde yaşayan ve kırsal kesimin önceliklerini en iyi şekilde irdeleyebilecek öğretmen, öğrenci ve veli paydaşlarının program geliştirme süreçlerine aktif katılımlarının sağlanmaması-

\footnotetext{
1 Ülkemizde ilk öğretmen yetiştirme okulu olan Dârülmuallimîn-i Rüşdi'nin açılmasından bu yana 167 (Hayta, 2009, s.1013) yıl geçmiştir. Buna rağmen araştırmalar, eğitim alanında, özellikle öğretmen eğitiminde halen istenilen noktaya ulaşılmadığını göstermektedir. OECD (2010) raporlarına göre eğitim ile ilgili araştırmaların büyük çoğunluğunda Türkiye, üye ülkeler arasında listenin ikinci yarısında, birkaçında ise son sıralarda yer, almaktadır. Bunun birçok sebebinin olduğu; ama bunlar içerisinde genelde Türkiye'nin eğitim politikası özelde öğretmen eğitimi ile ilgili olarak yapılan reformların kısa vadeli olması, değiş̧ikliklerin hükümetlerin iktidar süreleriyle hatta çoğu zaman millî eğitim bakanlarının ve YÖK başkanlarının hizmet süreleriyle sınırlı kalması, başat sebepler olarak gösterilebilir (Bulut, 2015, s.5). Eğitim politikaları tutarlı olan "Japonya ve Finlandiya gibi ülkelerde ise öğretmen eğitimi konusunda yapılan reform çalışmalarının çok uzun soluklu olduğu ve hiçbir siyasi otorite tarafindan uzun yıllar değiştirilmediği görülmektedir.” (Westbury, Hansen, Kansanen ve Björkvist'ten akt; Aksoy, 2013, s.2).
} 
nın tepeden inme, kırsaldan kopuk ve gerçeklikten uzak programların uygulanmasına neden olduğunu vurgulamaktadır. Nihayetinde "Eğitim sistemleri, toplumların hedef ve ihtiyaçlarını karşılayabildikleri sürece başarılı kabul edilebilirler." (Güzel, 2010, s.372).

\section{Çalışmanın Amacı ve Önemi}

Nitelikli bir eğitim için her şeyden önce eğitimi nitelikli hâle getirmeye engel teşkil eden olumsuz durumların giderilmesi zorunludur. $\mathrm{Bu}$ nedenle genelde öğretmenlerin özelde de kırsal kesimde çalışan öğretmenlerin sorunlarının tespit edilmesi, bu sorunların giderilmesi için neler yapılabileceğinin düşünülmesi büyük önem arz etmektedir.

$\mathrm{Bu}$ çalışmanın amacı, kırsal kesimde çalışan Türkçe ve sınıf öğretmenlerinin, mesleğin ilk yıllarında karşılaştıkları sorunları tespit etmek ve bu sorunların giderilmesine yönelik çözüm önerilerini ortaya koymaktır. Öğrencilikten henüz çıkmışken belki de hiç bilmedikleri bölgelere atanan gençlerin hem yeni bir yere yerleşmeden hem de mesleğe yeni başlamış olmaktan dolayı uyum ihtiyacı içinde oldukları (Toker-Gökçe, 2013) bilinen bir gerçektir. Dolayısıyla söz konusu öğretmenlerin sıkıntıları ve bu sıkıntıların çözüm yollarından hareketle uyum sürecini irdelemek bu çalışmanın kapsamında yer almaktadır. Çalışma Van ilinin kırsal kesiminde çalışan Türkçe ve sınıf öğretmenleriyle yürütülmüştür. Çalışma için özellikle Türkçe ve sınıf öğretmenlerinin seçilmesinin sebebi, kırsal kesimdeki öğretmenlerin mesleklerini icra ederken karşılaştıkları ilk ve belki de en önemli problemin dil ve iletişim ile ilgili olmasıdır. Bu durum, Türkçe ve sınıf öğretmenlerinin kırsal kesimde görev yapan öğretmenler arasında söz konusu problemlerle karşılaşan ilk kesim öğretmenler oldukları anlamına gelmektedir.

"Eğitimde mevcut sorunların çözümü, ülke gerçeklerine uygun planlamanın hazırlanması ve uygulamasında bilimsel araştırmalar esas alınmalıdır." (Dikenoğlu, 1992, s.448). Bundan hareketle bu çalışmayla kırsal ile ilgili çokça dile getirilen sorunların bilimsel olarak tespit edilmesi hedeflenmiştir. Çalışmada öğretmenlerin ne tür sorunlarla karşılaştıkları, sorunları nasıl çözdükleri ve daha farklı ne tür çözüm önerileri sundukları tespit edilmeye çalışılmış ve böylece meslekî dayanışma ve işbirliği için önemli olan bilgi ve tecrübeler paylaşılmıştır. Yukarıdaki genel amaç çerçevesinde aşağıdaki sorulara yanıt aranmıştır:

Kırsal kesimde görev yapan ve mesleğin ilk yıllarında olan Türkçe ve 
sinıf öğretmenlerinin;

1. Kırsal kesime atanmış olmalarından dolayı yaşadıkları sorunlar ve bu sorunlara karşı geliştirdikleri çözümler nelerdir?

2. Öğretmenlere göre (kırsal kesim ile merkezi karşılaştırdıklarında) kırsalın sorunları nelerdir?

3. Kültürel koşullar bakımından eğitim-öğretim faaliyetlerinde yaşanan sorunlar ve geliştirilen çözümler nelerdir?

4. Öğretmenlerin kırsal kesimde yaşanan problemlerin çözümü için Millı̂ Eğitim Bakanlığı'na, eğitim fakültelerine, okul idarecilerine ve mesleğe yeni başlayacak olan öğretmen adaylarına önerileri nelerdir?

\section{Yöntem}

Araştırma durum çalışmasına (case study) göre yürütülmüştür. Durum çalışması "Güncel bir olguyu kendi gerçek yaşam çerçevesi (içeriği) içinde çalışan, olgu ve içinde bulunduğu içerik arasındaki sınırların kesin hatlarıyla belirgin olmadiğl ve birden fazla kanıt veya veri kaynağının mevcut olduğu durumlarda kullanılan, görgül bir araştırma yöntemidir." (Yin, 1984'den akt; Y1ldırım ve Şimşek, 2011, s.277). Diğer araştırma türlerinden ayrılan yanlarından yola çıkarak, durum çalışmasının "nasıl”" ve "niçin" sorularını temel alan, araştırmacının kontrol edemediği bir olgu ya da olayı derinliğine incelemesine olanak veren araştırma yöntemi olduğu söylenebilir (Yıldırım ve Şimşek, 2011).

Çalışmada veriler nitel araştırma yöntemine göre toplanmıştır. Gözlem, görüşme ve doküman analizi gibi nitel veri toplama yöntemlerinin kullanıldığı, algıların ve olayların doğal ortamda gerçekçi ve bütüncül bir biçimde ortaya konmasına yönelik nitel bir sürecin izlendiği araştırma (Yıldırım ve Şimşek, 2011) olarak tanımlanan nitel çalışmalarda veri elde etmek için kullanılan yollardan birisi de bireylerin görüşlerine başvurmadır. İnsanların tecrübeleri, fikirleri, eleştirileri, beğenileri, duyguları, tutumları, inanç ve ideolojileri ile ilgili bilgi edinmek için başvurulan bu yol bilimsel çalışmalarda son derece etkili bir yöntemdir. Çalışmada elde edilen veriler içerik analizi kullanılarak analiz edilmiştir.

\section{Çalışma Grubu}

Araştırmanın çalışma grubunu Türkiye'nin doğusunda yer alan illerden 
biri olan Van ilinin kırsal kesiminde çalışan 11'i sınıf, 9'u Türkçe öğretmeni olmak üzere toplamda 20 öğretmen oluşturmaktadır. Çalışma grubu belirlenirken özellikle merkeze uzak köylerde ve ilçelerde görev yapan öğretmenlere ulaşılmaya çalışılmıştır. Çalışmaya 1-3 yıl arasında meslekî tecrübeye sahip öğretmenler katılmıştır.

\section{Veri Toplama Aracı}

Çalışmada yer alan öğretmenlere sorulacak soruları içeren bir "Görüş Alma Formu" hazırlanmıştır. Bu formun hazırlanması için ilgili alanyazın ayrıntılı olarak incelenmiş ve birçok soru hazırlanmıştır. Bu sorular üzerinde yapılan çalışma sonrasında amaca hizmet edebilecek sorular seçilmiştir. Böylece hazırlanan form, görüş ve önerilerinden yararlanmak üzere alan uzmanlarıyla paylaşılmıştır. Gelen dönütler doğrultusunda görüş alma formu yeniden düzenlenerek son hali verilmiştir. Bu işlemlerin sonunda "Kırsal Kesime Atanan Türkçe ve Sınıf Öğretmenlerinin Mesleğe Uyum Süreci Görüş Alma Formu"nda, araştırmanın amacına hizmet edeceği düşünülen çeşitli alt boyutlara sahip beş soru yer almıştır.

\section{Verilerin Toplanması}

Verilerin toplanması sürecinde gönüllü olan öğretmenlerle iletişime geçilmiştir. Görüş alma formu ya elden ya da e-posta aracılığıyla öğretmenlere ulaştırılmış, formda yer alan açık uçlu sorulara yazılı olarak cevap vermeleri istenmiştir. Öğretmenlerle iletişim sürdürülerek verilerin toplanmasında eksik olan kısımlar tamamlanmıştır.

\section{Verilerin Analizi}

Veriler nitel çözümleme tekniklerinden içerik analizine göre analiz edilmiştir. Bu süreçte dört merhale izlenmiştir: Verilerin kodlanması, temaların bulunmas1, verilerin temalara ve kodlara göre düzenlenmesi, bulguların yorumlanması. Veriler sınıf ve Türkçe öğretmenlerinin karşılaştıkları durumlar açısından bazen farklılaşmış bazen de benzerlik göstermiştir.

\section{Geçerlik ve Güvenirlik}

$\mathrm{Bu}$ çalışmanın her aşamasında özellikle ihtiyaç durumunda uzmanların (alan uzmanları ve ölçme-değerlendirme uzmanları) görüşlerine başvurulmuştur. Böylece araştırmanın geçerliğini sağlamak için gerçek bilgiler elde edilmeye çalışılmıştır. Durum var olduğu şekliyle ve herhangi bir müdahale olmadan yansıtılmaya çalışılmıştır. Güvenirlik için ise kodlayıcıların fikir 
birliğine başvurulmuştur. Verilerin tamamı araştırmacılar tarafindan birlikte analiz edilmiştir. Kodlayıcılar arasında fikir birliği sağlanmıştır.

\section{Bulgular}

Türkçe ve sınıf öğretmenlerine uygulanan "Kırsal Kesime Atanan Türkçe ve Sinıf Öğretmenlerinin Mesleğe Uyum Süreci Görüş Alma Formu"nda beş soru yer almıştır. Sorulara ilişkin öğretmenlerin görüşleri başlıklar hâlinde incelenmiş ve aşağıda sunulmuştur.

Kırsal kesime atanmış olmalarından dolayı sınıf ve Türkçe öğretmenlerinin yaşadıkları sorunlar ayrı ayrı ele alınmıştır. Öğretmenlerin yaşadıkları problemlerin bir kısmı aynı bir kısmı ise farklılık göstermektedir. Bununla ilgili veriler Tablo 1'de yer almaktadır.

Tablo 1. Öğretmenlerin Kırsal Kesime Atanmış Olmalarından Dolayı Yaşad1kları Sorunlar

\begin{tabular}{lll}
\hline Temalar & Sınıf Öğretmeni & Türkçe Öğretmeni \\
\hline Aile & Veli ilgisizliği (4) & Maddi yetersizlik (3) \\
& Maddî yetersizlik (3) & Veli ilgisizliği (3) \\
& Okuma-yazma bilmeme (2) & Bilinçsizlik (2) \\
& İletişimsizlik (1) & \\
\hline Öğrenci & Dile hâkim olmama (2) & Derse ilgisizlik (3) \\
& Düşük başarı (2) & Çalışma (çobanlık) (2) \\
& Temizlik (2) & İhtiyaçlarının karşılanmaması (1) \\
& Derse ilgisizlik (1) & Sosyal aktivitelerin kısıtlılığ (1) \\
& Arkadaşlarıyla uyumsuzluk (1) & Düşük başarı (1) \\
& Okulöncesi eğitim almama (1) & Dile hâkim olmama (1) \\
& & İletişim (1) \\
\hline Okul & Ulaşım (5) & Ulaşım (3) \\
& Kisıtlı imkânlar (1) & Ders materyallerinin eksikliği (3) \\
& Kalabalık sınıflar (1) & Fiziksel yetersizlik (2) \\
& & Teknik sorunlar (elektrik, internet, \\
& & vb.) (2) \\
& & Kalabalık sınıflar (2) \\
& & Temizlik (1) \\
& & Merkeze uzaklık (1)
\end{tabular}

Kırsal bölgelerde görev yapan sınıf ve Türkçe öğretmenlerinin karş1laştıkları problemler aile, öğrenci ve okul temalarında toplanmaktadır. Buna göre aile temasında hem sınıf öğretmenleri hem de Türkçe öğretmenlerinin 
çoğunluğu velilerin ilgisizliği ve maddî yetersizlik konularında ortak problemler yaşamaktadır. Bunun yanı sıra sınıf öğretmenleri öğrencilerin okuma-yazma bilmemeleri ve onlarla iletişim kuramamaları konusunda, Türkçe öğretmenleri ise öğrencilerin bilinçsiz olmalarından dolayı sorun yaşamaktadir.

Öğrenci temasında yaşanan ortak problemler dile hâkim olmama, düşük başarı ve derse ilgisizlik olarak görülmektedir. Sınıf öğretmenlerinin ayrıca problem yaşadıkları diğer hususlar öğrencilerin okul öncesi eğitim almamaları, temizlik ve arkadaşlarıyla uyumsuzluk iken Türkçe öğretmenlerinin karşılaştığı sorunlar öğrencilerin çalışması (çobanlık), ihtiyaçlarının karş1lanmaması, sosyal aktivitelerin kısıtlı olması ve iletişimdir.

Okul temasında iki branş öğretmeni de yaşanan en önemli problemin ulaşım olduğunu ifade etmişlerdir. Diğer ortak bir problem ise kalabalık sınıflardır. Sınıf öğretmenlerinin bu kategoride ayrıca yaşadığı problemler kısıtlı imkânlar iken, Türkçe öğretmenlerinin karşılaştığı problemler ders materyallerinin eksikliği, merkeze uzaklık, teknik sorunlar, temizlik, fiziksel yetersizliktir. Öğretmenlere yaşadıkları bu problemleri nasıl çözüme kavuşturdukları sorulmuştur. Öğretmenlerin geliştirdikleri çözüm önerileri aşağıdaki tabloda yer almaktadır.

Tablo 2. Öğretmenlerin Yaşadıkları Problemlere Karşı Geliştirdikleri Çözümler

\begin{tabular}{lll}
\hline Temalar & Sinıf Öğretmeni & Türkçe Öğretmeni \\
\hline Öğrenci & Örnek davranış (4) & Bireysel ilgi (2) \\
& Bireysel ilgi (2) & Çözümcü yaklaşım (2) \\
& Sabır (1) & Bilgilendirme (1) \\
& Çocuğa göre eğitim (1) & Görselleştirme (1) \\
& Sevgiyle yaklaşma (1) & \\
& Empati (1) & \\
& Ek çalışmalar (1) & \\
& Türkçe bilenler aracılığıyla anlaşma (1) & Meslektaş işbirliği (1) \\
\hline Öğretmen & Çevreye uyum sağlama (1) & Bireysel çaba (1) \\
& Fedakârlık (1) & Materyal sağlama (1) \\
& Deneyimli öğretmenlerle işbirliği (1) & Sorunlarla yaşamayı ögrenme \\
& Bireysel çaba (1) & (1) \\
& Okul içi öğretmen dayanışması (1) & \\
& İdare öğretmen işbirliği (1) & \\
& Karşıllklı öğrenme (dil-kültür) (1) & Bilgilendirme (2) \\
& Sürekli iletişim (2) & İsirliği (1) \\
\hline
\end{tabular}

Tablo 2 incelendiğinde sınıf öğretmenleri öğrencilerle ilgili problemleri 
çözmek için özellikle örnek davranış sergilemeye çalışmakta ve çocuklarla bireysel olarak ilgilendiklerini belirtmektedir. Bunun yanında sabır, empati kurma, sevgiyle yaklaşma başvurdukları diğer çözüm yollarıdır. Dil ile ilgili problemlerini ise Türkçe bilen çocuklar aracılığıyla çözmeye çalışmaktadırlar.

Türkçe öğretmenleri ise öğrencilerle bireysel olarak ilgilendiklerini, çözümcü yaklaştıklarını vurgulamaktadır. Hem sınıf öğretmenleri hem de Türkçe öğretmenleri kendileriyle ilgili problemleri çözme noktasında bireysel çaba gösterme, meslektaş işbirliği yapma gibi çözümler bulmuşlardır. Sınıf öğretmenleri bundan farklı olarak idare ile işbirliği ve öğrencilerle karşılıklı öğrenme (dil-kültür) gerçekleştirdiklerini belirtmişlerdir.

Veli ile ilgili sorunların çözümünde ise onları bilgilendirme, sürekli iletişim hâlinde olma ve onlarla işbirliği yapma çabaları olduğu görülmektedir.

Öğretmenlerden (kırsal kesim ile merkezi karşılaştırdıklarında) kırsalın sorunlarının neler olduğunu belirtmeleri istenmiştir. Öğretmenlerin görüşleri Tablo 3'te yer almaktadır.

Tablo incelendiğinde, merkez ile kırsal kesimi fiziksel koşullar aç1sından karşılaştırıldığında, kırsal kesimin merkeze oranla eksik olduğu pek çok husus görülmektedir. Bu eksikler fiziksel koşullar, hedef kitle ve sosyal çevre temalarında toplanmıştır. Hem sınıf hem de Türkçe öğretmenleri ulaşım (öğretmen-öğrenci), ev sorunu (öğretmen için barınma, öğrenci için çalışma ortamı), 1sınma-zor iklim şartları (öğretmen ve öğrenci için, soba vb.), teknolojik yetersizlikler, temizlik-okul ve çevrenin kirliliği konularında kırsalın merkeze göre daha olumsuz koşullara sahip olduğu görüşündedir. Bunun yanında Türkçe öğretmenleri okul imkânlarının yetersizliği (kütüphane, laboratuar, spor salonu, vb.) ve sınıfların kalabalıklığına dikkat çekerken sınıf öğretmenleri imkânsızlıklar, materyal eksikliği ve oyun alanlarının kısıtlı olmasından bahsetmişlerdir.

Hedef kitle açısından bir karşılaştırma yapıldığında iki branş öğretmeninin de dikkat çektiği hususlar eğitim seviyesinin düşüklüğü-düşük hazır bulunuşluk düzeyi, dil sorunu (öğrenmeyi olumsuz etkileme), veli ilgisizliğidir. Ayrıca sınıf öğretmenleri çocuklarda özgüven eksikliği, okul öncesi eğitim almama, teknolojiden uzak olma, kısıtlı sosyal çevre ve müfredatı uygulayamama problemlerini dile getirirken Türkçe öğretmenleri temel be- 
cerilerdeki eksiklik (konuşma, okuma, yazma, dinleme), öğrencilerin derse ilgisizliği ve bilinçsizliği, kelime eksikliği, sosyal faaliyet eksikliği, öğrencilerin çalışması (çobanlık) hususlarına dikkat çekmişlerdir.

Tablo 3. Öğretmenlere Göre (Kırsal Kesim ile Merkezi Karşılaştırdıklarında) Kirsalın Sorunları

\begin{tabular}{|c|c|c|}
\hline Temalar & Sınıf Öğretmenleri & Türkçe Öğretmenleri \\
\hline \multirow[t]{9}{*}{$\begin{array}{l}\text { Fiziksel } \\
\text { Koşullar }\end{array}$} & Ulaşım (öğretmen) (4) & $\begin{array}{l}\text { Okul olanaklarının yetersizliği (kütüphane, } \\
\text { spor salonu, vb.) (3) }\end{array}$ \\
\hline & Ulaşım (öğrenci) (4) & Ulaşım sıkıntısı (öğretmen-öğrenci) (2) \\
\hline & Ev sorunu (öğretmen) (4) & Öğrenciye ait çalışma ortamı olmaması (2) \\
\hline & Isınma (öğretmen-öğrenci) (3) & Okul ve çevrenin kirliliği (2) \\
\hline & İmkansızlıklar (3) & Sınıfların kalabalıklığı (1) \\
\hline & Materyal eksikliği (2) & Zor iklim şartları (1) \\
\hline & Teknolojik yetersizlik (2) & Teknolojik koşullar (1) \\
\hline & Temizlik (1) & Okul binasının eksikleri (1) \\
\hline & Kisitli oyun alanı (1) & \\
\hline \multirow{8}{*}{$\begin{array}{l}\text { Hedef } \\
\text { Kitle }\end{array}$} & Eğitim seviyesinin düşüklüğü (2) & Veli ilgisizliği (4) \\
\hline & $\begin{array}{l}\text { Dil probleminin öğrenmeyi } \\
\text { olumsuz etkilemesi (2) }\end{array}$ & Temel becerilerdeki eksiklik (3) \\
\hline & Çocuklarda özgüven eksikliği (2) & Düşük hazırbulunuşluk düzeyi (3) \\
\hline & Müfredatı uygulayamama (1) & Öğrencilerin derse ilgisizliği (2) \\
\hline & Veli ilgisizliği (1) & Öğrencilerin bilinçsizliği (2) \\
\hline & Okulöncesi eğitim almama (1) & Dil problemi (2) \\
\hline & Teknolojik gelişmelerden uzak & Kelime eksikliği (2) \\
\hline & $\operatorname{olma}(1)$ & Öğrencilerin çalışması (2) \\
\hline \multirow{8}{*}{$\begin{array}{l}\text { Sosyal } \\
\text { Çevre }\end{array}$} & K1sitlı sosyal çevre (4) & Sosyal faaliyet eksikliği (4) \\
\hline & $\begin{array}{l}\text { Okuma yazma oranının düşüklüğü } \\
\text { (3) }\end{array}$ & Öğretmenin kısıtlı çevresi (2) \\
\hline & Maddi yetersizlikler (2) & Teknolojiden uzak olma (2) \\
\hline & Sosyal faaliyetlerin yetersizliği (2) & Okuma teşvikinin olmaması (1) \\
\hline & Olumsuz örnekler (2) & Okuma oranının düşüklüğü (1) \\
\hline & $\begin{array}{l}\text { Kız çocuklarını okula gönderme- } \\
\text { me ve erken yaşta evlilik (1) }\end{array}$ & Çevreye duyarsızlık (1) \\
\hline & Veli ilgisizliği (1) & D1ş dünyaya açılamama (1) \\
\hline & Veli bilinçsizliği (1) & \\
\hline
\end{tabular}

Sosyal çevre açısından öğretmenlerin vurguladıkları en önemli hususlar sosyal faaliyet eksikliği, kısıtlı sosyal çevre, okuma yazma oranının düşük olması ve maddî yetersizliklerdir. Sınıf öğretmenlerinin dikkat çektiği diğer bir husus da kız çocuklarının okutulmaması ve erken yaşta evliliktir.

Öğretmenlerin kültürel koşullar bakımından eğitim-öğretim faaliyetlerinde yaşadıkları sorunlar ve çözüm önerileri değerlendirildiğinde Tablo 
4'teki durum ortaya çıkmaktadır.

Tablo 4. Kültürel Koşullar Bakımından Eğitim-Öğretim Faaliyetlerinde Yaşanan Sorunlar ve Çözümler

\begin{tabular}{lll}
\hline Temalar & Sınıf Öğretmeni & Türkçe Öğretmeni \\
\hline Problemler & Veli ilgisizliği (4) & Veliyle iletişim kuramama (kadın- \\
& Dil problemi (2) & larla konuşamama) (3) \\
& Geleneksel aile yapısı (1) & Ailenin eğitim-öğretimi destekle- \\
& & memesi (2) \\
& Eğitimi ciddiye almama (1) & Kız çocuklarının okutulmaması (1) \\
& & Dil problemi (1) \\
& & Sosyal-sanatsal faaliyetlere ilgisizlik \\
& & $(1)$ \\
\hline Cözüm & Velileri bilgilendirme (2) & Farklı kaynaklara ulaşamama (1) \\
Yolları çözümler (1) & Veli ziyaretleri (2) & Velileri bilgilendirme (1) \\
& Velilerle iletişim (2) & Öğrencileri bilgilendirme (1) \\
& Kişisel çabalar (derste ek & Sosyal etkinliklere teşvik (1) \\
& etkinlikler yapma) (3) & Olumlu yaklaşma (1) \\
& Öğrencinin yaşantısını eğitim & Ek ders materyalleri sağlama (1) \\
& öğretime katma (1) & Öğrencide farkındalı oluşturma (1) \\
& Türkçe bilen öğrencileri aracı & Meslektaşlardan yardım alma (1) \\
& olarak kullanma (1) & \\
\hline
\end{tabular}

Öğretmenler görev yaptıkları bölgenin kültürel koşullarının eğitim-öğretim faaliyetlerine etkisini değerlendirdiklerinde, yaşanan sorunlar sınıf ögretmenleri açısından veli ilgisizliği, dil problemi, geleneksel aile yapıs1, eğitimi ciddiye almama olarak görülmektedir. Türkçe öğretmenlerine göre ise veliyle iletişim kuramama (erkek öğretmenler öğrenci anneleriyle görüşemiyor), ailelerin eğitim-öğretimi desteklememesi, kız çocuklarının okutulmaması, dil sorunu, sosyal-sanat faaliyetlerine ilgisizlik ve farklı kaynaklara ulaşamama yaşanan problemlerden bazılarıdır.

Bu problemlerin çözümü için öğretmenler, veli ziyaretleri gerçekleştirip velileri bilgilendirdiklerini, velilerle iletişim kurmaya çalıştıklarını belirtmekte, eğitsel sorunlar için derste ek uygulamalar yapma, materyal sağlama, öğrencide farkındalık oluşturma gibi çözüm yollarına başvurduklarını belirtmişlerdir.

Kırsalda görev yapan öğretmenler yaşadıkları problemlerin çözümü için Millî Eğitim Bakanlığı, eğitim fakülteleri, okul idarecileri ve mesleğe 
yeni başlayan öğretmenlere birtakım önerilerde bulunmuştur. Öğretmenlerin önerileri aşağıdaki tabloda yer almaktadır.

Tablo 5. Öğretmenlerin Kırsal Kesimde Yaşanan Problemlerin Çözümü İçin Millî Eğitim Bakanlığı'na, Eğitim Fakültelerine, Okul İdarecilerine ve Mesleğe Yeni Başlayacak Olan Öğretmen Adaylarına Önerileri

\begin{tabular}{|c|c|c|}
\hline Temalar & Sınıf Öğretmeni & Türkçe Öğretmeni \\
\hline \multirow[t]{6}{*}{ MEB } & $\begin{array}{l}\text { Okullara daha fazla destek verilmeli } \\
\text { (4) } \\
\text { Okulların fizikî koşulları iyileştiril- } \\
\text { meli (4) }\end{array}$ & $\begin{array}{l}\text { Eğitim materyalleri merkezle } \\
\text { eşitlenmeli (3) } \\
\text { Ailelere eğitim verilmeli (2) }\end{array}$ \\
\hline & Teknik destek sağlanmalı (2) & $\begin{array}{l}\text { Okulların fizikî şartları iyileşti- } \\
\text { rilmeli (1) }\end{array}$ \\
\hline & $\begin{array}{l}\text { Öğretmene maddî-manevî destek } \\
\text { sağlanmalı (2) }\end{array}$ & Sosyal aktiviteler arttırılmalı (1) \\
\hline & $\begin{array}{l}\text { Öğretmenlerin barınma sorunu } \\
\text { çözülmeli (2) }\end{array}$ & $\begin{array}{l}\text { Öğretmenlere maddî destek sağ- } \\
\text { lanmalı (1) }\end{array}$ \\
\hline & $\begin{array}{l}\text { Öğretmeni geliştirici eğitimler ve- } \\
\text { rilmeli (2) }\end{array}$ & $\begin{array}{l}\text { Öğretmene kırsalla ilgili hizmet } \\
\text { içi eğitim verilmeli (1) }\end{array}$ \\
\hline & $\begin{array}{l}\text { Eğitim-öğretim materyalleri arttı- } \\
\text { rilmalı (2) }\end{array}$ & $\begin{array}{l}\text { Merkezdeki öğrencilerle kırsalda- } \\
\text { ki öğrenciler kaynaştırılmalı (1) }\end{array}$ \\
\hline \multirow[t]{6}{*}{$\begin{array}{l}\text { Eğitim } \\
\text { Fakültelerine }\end{array}$} & $\begin{array}{l}\text { Teoriden çok pratik uygulamalara } \\
\text { yer verilmeli (6) }\end{array}$ & $\begin{array}{l}\text { Kırsal bölgede staj imkânı olmalı } \\
\text { (2) }\end{array}$ \\
\hline & $\begin{array}{l}\text { Öğretmen adayları zor şartlara ha- } \\
\text { zırlanmalı (köy okulları, birleştiril- } \\
\text { miş sınıf) (4) }\end{array}$ & $\begin{array}{l}\text { Öğretmen meslekî zorluklara } \\
\text { hazırlanmalı (2) }\end{array}$ \\
\hline & Staj dersi ve kredisi arttırılmalı (2) & $\begin{array}{l}\text { Örnek durum çalışmaları yapıl- } \\
\text { malı (2) }\end{array}$ \\
\hline & $\begin{array}{l}\text { Köy okullarında staj imkânı veril- } \\
\text { meli (2) }\end{array}$ & $\begin{array}{l}\text { Okul deneyimine önem verilmeli } \\
\text { (1) }\end{array}$ \\
\hline & $\begin{array}{l}\text { Staj dersi 1. sinıftan itibaren veril- } \\
\text { meli (1) }\end{array}$ & Son iki sınıfta staj olmalı (1) \\
\hline & Öğretmen kalitesi arttırılmalı (1) & $\begin{array}{l}\text { MEB ile fakülteler işbirliği yap- } \\
\text { malı (gönüllü öğretmenlik) (1) }\end{array}$ \\
\hline \multirow[t]{5}{*}{$\begin{array}{l}\text { Okul } \\
\text { İdarecilerine }\end{array}$} & Öğretmene destek olmalı (4) & $\begin{array}{l}\text { Okul-aile işbirliğine önem vermeli } \\
\text { (2) }\end{array}$ \\
\hline & Fizikî koşullar iyileştirilmeli (2) & Öğretmene destek vermeli (2) \\
\hline & Okul-aile işbirliği arttırılmalı & Anlayışlı olmalı (1) \\
\hline & Öğretmene baskı kurmamalı (1) & Öğrencilerle ilgili olmalı (1) \\
\hline & Hoşgörülü olmalı (1) & \\
\hline
\end{tabular}


Aday

Öğretmenlere

Kend

Sabirlı olmalı (2)

Özverili olmalı (2)

Öğrencilere eşit davranmalı (2)

Çocukları sevmeli (2)

Krizleri yönetebilmeli (1)
Mesleğini sevmeli (2)

Kendini geliştirmeli (2)

Kırsal koşullara kendini hazırlamalı (1)

Sabirlı olmalı (1)

Kendini geliştirmeli (1)

Mesleğini sevmeli (1)

Öğrencilerini sevmeli (1)

Büyük beklenti içinde olmamalı

(1)

Görev yapacakları yerde daha çok Öğrencileri yadırgamamalı (1)

Öğretmenlerin önerdiklerine göre Millî Eğitim Bakanlığı'nın yapması gerekenler okulların fizikî koşullarını iyileştirmek, eğitim materyallerini merkezle eşitlemek, teknik destek sağlamak, öğretmenlere maddî-manevî destek sağlamak, öğretmenlerin barınma sorununu çözmek, eğitim-öğretim materyallerini arttırmak, öğretmenleri geliştirici eğitimler vermek, ailelere çeşitli eğitimler vermek, sosyal aktiviteleri arttırmak, öğretmenleri maddî olarak desteklemek, öğretmenlere kırsalla ilgili hizmet içi eğitim vermek, merkezdeki öğrencilerle kırsaldaki öğrencileri kaynaştırmaktır.

Kırsalda görev yapan öğretmenler, Türkiye'de öğretmen yetiştiren kurumlar olan eğitim fakültelerine de çeşitli önerilerde bulunmuşlardır. Mezun oldukları kurumların öğretmen yetiştirirken nelere dikkat etmeleri gerektiğini vurgulayan öğretmenlerin söyledikleri, hem eğitim fakültelerinde okumuş olmalarından hem de kırsalda görev yapıyor olmalarından dolayı önemlidir. Öğretmenlere göre teoriden çok pratik uygulamalara yer verilmeli, öğretmen adayları zor şartlara hazırlanmalı (köy okulları, birleştirilmiş sınıf gibi), staj dersi ve kredisi arttırılmalı, staj dersi daha erken sınıftan itibaren verilmeli, örnek durum çalışmaları yapılmalı, MEB ile fakülteler gönüllü öğretmenlik gibi çalışmalarla işbirliği yapmalıdır.

Bir okuldaki idareci ve öğretmenlerin ilişkileri o kurumdaki hizmet kalitesini şüphesiz ki etkilemektedir. Bu durum kırsaldaki okullar için daha büyük önem arz etmektedir. Çünkü öğretmenlerin herhangi bir durumda müracaat edecekleri ilk kişiler okul idarecileridir. Öğretmenler bu bağlamda okul idarecilerine öğretmenlere destek olmaları, fiziksel koşulları iyileştirmek için çaba göstermeleri, okul-aile işbirliğini arttırmaları, öğretmenlere baskı kurmamaları, öğretmenlere karşı hoşgörülü ve anlayışlı olmaları, öğrencilerle 
daha çok ilgilenmeleri şeklinde önerilerde bulunmaktadır.

Araştırmanın çalışma grubunu 1-3 yıllık tecrübeye sâhip öğretmenler oluşturmaktadır. Buna göre çalışma grubunu oluşturan öğretmenler meslekte belli bir tecrübe edinmiş olmakla birlikte kırsal ile ilgili edindikleri tecrübeler henüz güncelliğini korumaktadır. Bu nedenle kendilerinden sonra kırsal kesime atanacak öğretmenlere tavsiyeleri kırsal alanın problemlerinin azaltılmasına katkıda bulunacaktır. Görüşmelerde yer alan öğretmenler yeni atanacak ve görev yerleri kırsal kesim olacak öğretmenlere kendilerini her koşula (kırsal vs.) hazırlamalarını, mesleklerini sevmelerini, sabırlı ve özverili olmalarını, öğrencileri sevmelerini, yadırgamamalarını ve onlara eşit davranmalarını, krizleri yönetebilmelerini, kendilerini geliştirmelerini, büyük beklenti içinde olmamalarını, görev yapacakları yerde daha çok vakit geçirmelerini önermektedir.

\section{Sonuç ve Tartışma}

$\mathrm{Bu}$ çalışmada sınıf ve Türkçe öğretmenlerinin yaşadıkları sorunlar, bu sorunları çözme yolları ve bundan hareketle söz konusu öğretmenlerin mesleğe uyum süreci irdelenmiştir.

Toplumu oluşturan bireylerin, meydana gelen değişikliklere uyum sağlamalarında ve topluma katkıda bulunmalarında eğitim kurumlarına ve bu kurumlarda çalışan öğretmenlere önemli görevler düşmektedir (İzci, Duran ve Taşar, 2010). Genelde öğretmenlerin özelde de kırsal kesimde görev yapan öğretmenlerin karşılaştığı birçok sorun söz konusudur. Bu sorunların birçoğu kırsalın şartlarıyla ilgiliyken bir kısmı Millî Eğitim Bakanlığı'nın, eğitim fakültelerinin ve diğer paydaşların yapması gerekenleri istenilen seviyede yerine getirmemesinden kaynaklanmaktadır.

Türkiye'de eğitim sisteminde akademik başarının ön plana çıktığı görülmektedir (Yıldırım, 2010). Bu durum, lisans döneminde öğretmen adaylarının yeterince uygulama yapmaması anlamına gelmektedir. Oysaki öğretmenlik meslek becerisi, daha çok uygulama yapılarak edinilecek bir beceridir. Bu çalışmanın yapıldığı öğretmenler de teoriden çok uygulamaya önem verilmesi gerektiğini vurgulamışlardır.

$\mathrm{Bu}$ çalışmada ortaya konulan sorunların bir kısmı teknolojik yetersizlikler, materyal eksikliği, olumsuz ekonomik şartlar, iletişim, ulaşım, barınma, 1sınma, kısıtlı okul imkânları, çevre koşulları ve geleneksel anlayışla ilgilidir. Anılan, Kılıç ve Demir (2015) yaptıkları çalışmada materyal ve 
teknoloji eksikliği, öğretim programlarının kırsal alanın özelliklerini dikkate almaması gibi nedenlerden kaynaklanan sorunlar yaşadıklarını bulgulamışlardır. Ayrıca aynı çalışmada öğretmenler bireysel olarak konaklama ve şehre ulaşım gibi konularda da sıkıntı yaşamaktadırlar. Babacan (2006)'ın çalışmasında çevresel koşulların sosyal, ekonomik ve kültürel yapıyı etkilediği, bu etkileşimin de eğitim faaliyetlerine yansıdığı tespit edilmiştir. Araştırmacı kırsal yerleşmelerin kent merkezlerine uzaklığ1, coğrafî konum ve yeryüzü şekillerinin eğitim hayatı üzerinde doğrudan etki oluşturduğunu ifade etmektedir. Atalay ve Anagün (2014)'ün çalışmasının sonuçlarına göre öğretmenlerin yarısı çalıştıkları okulun fizikî koşullarını, bilgi ve iletişim teknolojilerini kullanma bakımından yetersiz olarak nitelendirmiştir. Taşkaya, Turhan ve Yetkin (2015) ise öğretmenlerin ulaşım, barınma (lojman eksikliği-yetersizliği), ısınma ve soba yakma konularında, dil konusunda, okulların donanım ve eğitim materyali eksikliği, okulların fizikî şartlarının yetersizliği (derslik eksiği-yetersizliği, tuvalet olmayışı-yetersizliği vb.) konularında sorunlarla karşılaştıklarını vurgulamışlardır. Kozikoğlu (2016) aday öğretmenlerle yaptığı çalışmada, öğretmenlerin en çok okulun fiziki altyapısı, olanaklarının yetersizliği nedeniyle ve sınıf yönetiminde güçlük yaşadıklarını ifade etmiştir. Şahin (2010) de çalışmasında öğretmenlerin ilk okuma yazma öğretimi sürecinde; meslekî gelişimlerinden, müfredat programından, çalıştıkları okulların fizikî şartlarından şikayet ettiklerini ifade etmiştir.

$\mathrm{Bu}$ çalışmanın bir diğer önemli sonuçlarından birisi de öğretmenlerin sosyo-kültürel açıdan çeşitli sıkıntılar dile getirmesidir. Çalışmada öğretmenler genel anlamda sosyal faaliyetlere ilgisizlikten yakınmışlardır. Bu ilgisizliğin özellikle köylerde sosyal faaliyet yapma konusunda yeterince imkân olmamasından kaynaklanmış olduğu düşünülmektedir. Özpınar ve Sarpkaya (2010)'nın yaptıkları çalışmada köyde görev yapan sınıf öğretmenleri, kültürel faaliyetlerden yoksun kaldıklarından (tiyatro, sinema) şikâyet etmişlerdir.

Çalışmamızda öğretmenler, yukarıda dile getirdikleri sorunları örnek davranışlar sergileyerek, öğrencilerle bireysel olarak ilgilenerek, problemlere çözüm odaklı ve sevgiyle yaklaşarak, meslektaşları ve idare ile işbirliği yaparak, öğrencilerle karşıllılı öğrenerek (dil-kültür), velilerle iletişim kurmaya çalışarak, eğitsel sorunlar için derste ek uygulamalar yaparak çözmeye çalıştıklarını ifade etmişlerdir. Bu alanda yapılan çalışmalara bakıldığında benzer sonuçlarla karşılaşmak mümkündür. Anılan, Kılıç ve Demir (2015)'in yaptığı 
çalışmada kırsal alanlarda görev yapan sınıf öğretmenlerinin uyum sağlamak için ev ziyaretleri yaptıkları ve özel günlere (dügün, nişan gibi) katıldıkları görülmektedir.

$\mathrm{Bu}$ çalışmada öğretmenler öğrenci ve ailelerin bilinçsizliğinden, velilerin ilgisizliğinden sıkça bahsetmişlerdir. Erdoğan ve Demirkasımoğlu (2010) da yaptıkları çalışmada ailelerin çoğunun eğitim sürecine katılım konusunda isteksiz ve pasif olduğunun görüldügünü belirtmişlerdir. Çiftçi (2010), yaptığ 1 çalışmada kırsal bölgelerde görev yapan matematik öğretmenlerinin aile eğitimsizliği, öğretmen eksikliği, teknolojik ve ekonomik yetersizliklerden dolayı matematik eğitiminde sorunlar yaşadığını ve okullarındaki öğrencilerin başarılarının bu nedenlerden dolayı daha iyiye gidemeyeceğini düşündüklerini vurgulamışlardır. Anılan, Kılıç ve Demir (2015) çalışmalarında öğretmenlerin sınıfların kalabalık olması, velilerin ilgisizliği ve eğitim seviyelerinin düşük olması, öğrencilerin derslere karşı ilgisizliği gibi durumlardan şikâyet etmişlerdir. Taşkaya, Turhan ve Yetkin (2015) de öğretmenlerin öğrenci ve velilerin eğitime karşı ilgisiz olduklarını vurgulamışlardır. Şahin (2010) ise öğretmenlerin eğitimin paydaşlarından kaynaklanan (öğrencilerden, velilerden, okul idaresinden, öğretmenden) problemlerle karşılaştıklarını ifade etmiştir.

Öğretmenlerin eğitim paydaşlarına getirdikleri çözüm önerileri ise okulların fizikî koşullarının ve eğitim materyallerinin merkezdeki okullarla eşitlenmesi, öğretmenlerin desteklenmesi (maddî-manevî) öğretmen adaylarının zor şartlara hazırlanması (köy okulları, birleştirilmiş sınıf), kırsal bölgede staj imkânı verilmesi, eğitim fakülteleri ile MEB'in sürekli iletişim ve işbirliği içinde olunması, okul-aile işbirliğine önem verilmesi, öğretmenlerin kendilerini her koşula hazırlayarak mesleklerini sevmeleri, sabırlı olmaları, öğrencilerini sevip onlara eşit davranmaları ve büyük beklentiler içinde olmamaları, şeklindedir.

Hem bu çalışmada hem de yukarıdaki çalışmalarda dile getirilen sorunları tetikleyen en önemli sebeplerden birisi de hiç şüphesiz ki kırsalda çalışan öğretmenlerin daha az tecrübeli olmasıdır. Gibbs (2000)' in ifade ettiği gibi kırsal kesimdeki öğretmenler daha az deneyimli ve daha gençtir. Bu nedenle buralarda görev yapan öğretmenler, söz konusu olumsuzluklardan dolayı daha s1k tayin istemektedirler. 


\section{Öneriler}

- MEB kırsal kesimde görev yapan köy öğretmenlerinin her türlü ihtiyacını gidermeli, özellikle fizikî koşulları iyileştirme konusunda daha hassas davranmalidır.

- Öğretmenlerin kırsal kesime atanırken yaşayacakları problemlerle (özellikle dil ve iletişim) baş edebilmeleri için lisans programlarına buna yönelik dersler konulmalıdır.

- Öğretmenlik uygulaması dersi son sınıfa bırakılmamalı, ikinci sınıftan itibaren olmalı ve sürece yayılmalıdır. Ayrıca bu dersin en az bir dönem kırsal kesimde yürütülmesi sağlanmalıdır.

- Öğretmen adaylarını Türkiye'nin her yerinde ve her koşulda çalışabilecek şekilde yetiştirmek eğitim fakültelerinin sorumluluğundadır.

Bu nedenle başta sınıf ve Türkçe öğretmen adayları olmak üzere bütün öğretmen adaylarının, kırsal kesimde özellikle de Doğu ve Güneydoğu Anadolu illerinin kırsal kesiminde öğretmenlik yapabilecek şekilde yetiştirilmesi gereklidir. Bu, Farabi Programı'na benzer bir ‘öğrenci değişim programı' aracılığıyla yapılabilir.

- Kırsal kesimde geleneksel hayatın getirdiği birtakım sorunların çözümü için köylerde çeşitli seminerler verilerek halk bu konuda aydınlatılmalidir.

- Kırsal kesimdeki öğrencilerin sosyal ve psikolojik durumları üzerine araştırmalar yapılarak eğitimle ilgili sorunların giderilmesi için çalışmalar yapılmalıdır.

- Eğitim fakülteleri, Millî Eğitim Bakanlığg ile sürekli işbirliği içinde olarak öğretmen adaylarının mesleki tecrübe kazanmaları için çalışmalar yürütmelidir (gönüllü öğretmenlik).

- Öğretmenlik uygulaması derslerine daha çok önem verilmeli, uygulamalar öğretim üyelerinin kontrolünde planlı ve programlı yürütülmelidir.

- Sonuç olarak öğretmen yetiştirme programları gözden geçirilerek öğretmenleri mesleğe hazırlayan uygulamalara ve her koşula hazırlayıcı derslere ağırlık verilmelidir. 


\section{Kaynakça}

Aksoy, E. (2013). A.B.D (New York), Finlandiya, Singapur ve Türkiye'de ögretmen eğitimindeki dönüşümler (2000-2010). Yayınlanmamış doktora tezi, Ankara Üniversitesi Eğitim Bilimleri Enstitüsü.

Anılan, H., Kılıç, Z. ve Demir, Z. M. (2015). Kırsal alanda öğretmen olmak: Sınıf öğretmenlerinin bakış açısı. Turkish Studies International Periodical For the Languages, Literature and History of Turkish or Turkic, 10(11), 149-172.

Aslan, S. (2013). Birleştirilmiş sınıflarda görev yapan öğretmenlerin "öğretmen" kavramı ile ilgili algılarının metaforik incelenmesi. Turkish Studies International Periodical for the Languages, Literature and History of Turkish or Turkic, 8(6), 43-59.

Atalay, N. ve Anagün, Ş. S. (2014). Kırsal alanlarda görev yapan sınıf öğretmenlerinin bilgi ve iletişim teknolojilerinin kullanımına ilişkin görüşleri. Eğitimde Nitel Araştırmalar Dergisi, 2(3), 9-27.

Babacan, R. (2006). Mesudiye ve Ayrancı köylerinde eğitim ve çevre ilişkileri. Yayınlanmamış yüksek lisans tezi, Afyon Kocatepe Üniversitesi Sosyal Bilimler Enstitüsü.

Bulut, K. (2015). Mikro ögretim tekniğinin Türkçe ögretmen adaylarının konuşma beceri ve kaygılarına etkisi. Yayınlanmamış doktora tezi, Gazi Üniversitesi Eğitim Bilimleri Enstitüsü.

Çiftçi, K. (2010). Kırsal bölgelerdeki matematik eğitimi sorunları: Öğretmen ve ögrrenciler açısından bir değerlendirme çalışması. Yayınlanmamış yüksek lisans tezi, Osmangazi Üniversitesi Fen Bilimleri Enstitüsü.

Dikenoğlu, A. (1992). Türk eğitim sisteminde temel sorunlar, planlama ve uygulama. Hacettepe Üniversitesi Eğitim Fakültesi Dergisi, 8(8), 445-448.

Erdoğan, Ç. ve Demirkasımoğlu, N. (2010). Ailelerin eğitim sürecine katıl1mına ilişkin öğretmen ve yönetici görüşleri. Kuram ve Uygulamada Eğitim Yönetimi Dergisi, 16(3), 399-431.

Eğitim Reformu girişimi-Eğitim İzleme Raporu (2011). Eğitimin bileşenleri: ögretmen ve öğrenme süreçleri (s. 78-103), 
https://erg.sabanciuniv.edu/sites/erg.sabanciuniv.edu/files/EIR2011.E. B.OgretmenOgrenme.pdf.

Gedikoğlu, T. (2005). Avrupa Birliği sürecinde Türk eğitim sistemi: sorunlar ve çözüm önerileri. Mersin Üniversitesi Eğitim Fakültesi Dergisi, 1(1), 66-80.

Gibbs, R. (2000). The challenge ahead for rural schools. Forum for Applaid Research \& Public Policy, 15(1), 82-86.

Gutek, G. L. (1988). Realizm ve eğitim. Eğitime ilişkin felsefi ve ideolojik görüşler (N. Kale, Çev.) içinde (s. 46-50). Ankara Üniversitesi Eğitim Bilimleri Fakültesi Dergisi, 26(1), 275-287.

Gül, H. (2014). Türkiye'nin eğitim sorunları, AKP'nin eğitime bakışı ve çözüm önerileri. Toplum ve Demokrasi Dergisi, 2(3), 181-196.

Güzel, A. (2010). Türkçe eğitimi bölümlerinde kurulması gerekli görülen ana bilim dalları. TÜBAR 27(1), 371-383.

Hayta, N. (2009). XX. yüzyıl başlarında dârülmuallimîn. Gazi Eğitim Fakültesi Dergisi, Prof. Dr. Reşat Genç'e Armağan Özel Sayısı, 1013-1022.

Horn, J. G. (1995). What is rural education? (Chapter 1). P. B. Otto, (Ed.), Science education in the rural United States: Implication for the Twenty-First Century içinde (1-14). Colombus: Ohio-ABD: ERIC/CSMEE.

İzci, E., Duran, H. ve Taşar, H. (2010). Birleştirilmiş sınıflarda öğretimin sınıf öğretmeni adaylarının algılarına göre ve birleştirilmiş sınıflarda görev yapan sınıf öğretmenlerinin görüşleri açısından incelenmesi. Ahi Evran Üniversitesi Ĕ̆itim Fakültesi Dergisi, 11(1), 19-35.

Kozikoğlu, İ. (2016). Öğretimin ilk yılı: Mesleğin ilk yllındaki öğretmenlerin karşılaştıkları güçlükler, hizmet öncesi eğitim yeterlikleri ve mesleğe adanmışlıkları. Yayınlanmamış doktora tezi, Yüzüncü Y1l Üniversitesi Eğitim Bilimleri Enstitüsü.

OECD. (2010). PISA 2009 at a Glance. OECD.

Özpınar, M. (2008). Köyde görev yapan ögretmenlerin sorunları-Aydın ili örneği. Yayınlanmamış yüksek lisans tezi, Adnan Menderes Üniversitesi Sosyal Bilimler Enstitüsü. 
Özpınar, M. ve Sarpkaya, R. (2010). Köyde görev yapan sınıf öğretmenlerinin sorunları. Pamukkale Üniversitesi Eğitim Fakültesi Dergisi, 27(27), 17-29.

Sağ, R. (2007). Öğretmen ĕgitiminde uygulama öğretmenliği uygulamasının değerlendirilmesi. Yayınlanmamış doktora tezi, Anadolu Üniversitesi Eğitim Bilimleri Enstitüsü.

Şahin, A. (2010). Kursal kesimde görev yapan öğretmenlerin ilk okuma ve yazma öğretiminde karşılaştıkları problemler. E-Journal of New World Sciences Academy, 5(4), 1738-1750.

Taşkaya, S. M., Turhan, M. ve Yetkin, R. (2015). Kursal kesimde görev yapan sınıf öğretmenlerinin sorunları (Ağrı ili örneği). Uluslararası Avrasya Sosyal Bilimler Dergisi, 16(18), 198-210.

Toker-Gökçe, A. (2013). Sınıf öğretmenlerinin adaylık dönemlerinde yaşadıkları mesleki sorunlar. Dicle Üniversitesi Ziya Gökalp Eğitim Fakültesi Dergisi, 21, 137-156.

Turan, S. ve Garan, Ö. (2008). Kırsal kesimde görev yapan sınıf öğretmenlerinin matematik öğretiminde karşılaştıkları güçlükler. Milli Eğitim, 170, 116-128.

Türkiye İstatistik Kurumu (TÜIK) (2011). Haber bülteni.

http://www.tuik.gov.tr/PreHaberBultenleri.do?id=10736

Türkiye İstatistik Kurumu (TÜíK) (2014). Haber bülteni. http://www.tuik.gov.tr/PreHaberBultenleri.do?id=18616

Türkiye İstatistik Kurumu (TÜíK) (2015). Haber bülteni. http://www.tuik.gov.tr/PreHaberBultenleri.do?id=21507

Webster, J. B. ve Fisher, D. (2000). Acoounting for variation in science and mathematics achievement: A multilevel analysis of Australian data third international mathematics and Science study (TIMSS). School Effectiveness and School Improvement, 11(3), 339-360.

Yıldırım, A. ve Şimşek, H. (2011). Sosyal bilimlerde nitel araştırma yöntemleri. Ankara: Seçkin.

Yıldırım, N. (2010). Kırsal bölgelerde öğrenim gören öğrencilere yönelik sosyal etkinlikler hakkında öğrenci, öğretmen görüşleri ve öğrencile- 
rin özsaygıları açısından değerlendirilmesi. İlköğretim Online, 9(3), 1080-1091. 